\title{
Long-term result after operative correction of funnel chest
}

\author{
SVEN BORGESKOV and DENNIS RAAHAVE \\ Department of Thoracic Surgery, University Hospital, Copenhagen
}

\begin{abstract}
During the last decades it has been commonly accepted that funnel chest is such a serious cosmetic handicap that it deserves correction for this reason alone.

A group of patients with this deformity, operated upon by the method of Paltia (transsternal fixation with metal struts), was re-examined 5 to 10 years postoperatively. In more than $50 \%$ of the cases the immediate acceptable cosmetic result had disappeared in contrast to the satisfaction expressed by almost all the patients. Because of the high incidence of recurrence and because of various risks involved in this operation, the authors do not advocate its performance.
\end{abstract}

Among the various deformities of the thorax, funnel chest (pectus excavatum) has attracted much attention.

Many authors consider funnel chest as a cause of cardiopulmonary symptoms (Hegemann and Schoberth, 1958 ; von Mallinckrodt and Gremmel, 1960; Dafoe and Ross, 1961; Flemming and Neute, 1966), while others are more doubtful (Brodkin, 1948 ; Myhre, 1955 ; Landtman, 1958 ; Ashmore, 1963 ; Zorab, 1966 ; Wohl, 1968).

The majority of patients with funnel chest have no organic symptoms, but the purely cosmetic aspect is of great significance for many. In this country, Hansen and Jacoby (1956) found reduced pulmonary function in four patients with funnel chest. Normal values were found after operation. Fabricius, Davidsen, and Hansen (1957) found no correlation between the degree of funnel chest and the severity of symptoms and concluded that the indication for operation in most cases was purely cosmetic.

Until about 1960, the operative procedure followed in the University Hospital, Copenhagen, was external fixation (Therkelsen, 1951, 1953). Since 1960, the patients have been operated upon by the method described by Paltia, Parkkulainen, Sulamaa, and Wallgren in 1959. Fixation is performed by means of metal struts introduced transversely through the sternum, after this has been totally mobilized by means of numerous chondrotomies. The patient is admitted to hospital for removal of the splints one year after the operation.

Although a number of patients come for treatment because of slight functional dyspnoea and palpitations, it most often is the purely cosmetic $\vec{\theta}$ complaint which is of decisive importance. As a.significant number of patients are still referredర for operation, we have considered it of interest to undertake a long-term follow-up of the results of the operation. Only a radiological and clinicalo evaluation has been undertaken in an attempt to $\mathbb{\perp}$ describe the cosmetic effect of the operation. The $\vec{\Rightarrow}$ changes in ECG, the heart shadow in the chest 3 radiograph, and lung function have not been recorded as they are well known from other series.0

\section{MATERIAL AND METHOD}

Kjær, Poulsen, and Vestengaard (1965) published a one-year follow-up study of a series of 25 patients, 3 . the majority of whom had been operated upon for funnel chest at the age of 10 to 14 years on a purely? cosmetic indication, with good results in 24 of the cases. The operations were performed in surgical department $\mathbf{R}$ of the University Hospital from 1960 to 1963.

The present material consists of 18 of the above mentioned patients. Of the original 25 patients, four are now resident abroad. In three patients radio 0 graphs could not be obtained, while the remaining 1 \& patients were examined clinically as well as radio- logically 7 to 10 years after operation.

Four of the 18 patients are women and 14 menfo Only two patients were under the age of 10 yearse at the time of operation, and only one was over 20 years old.

The radiological evaluation of funnel chest was made by means of the vertebral index. This is the diameter of the vertebral body in per cent of the्D thoracic diameter, measured at the level of the shortes? thoracic diameter in the lateral chest film (Backer, 
Brünner, and Larsen, 1961). The index increases normally to about the age of 6 years, after which it remains constant.

\section{RESULTS}

The result of the operative treatment is shown graphically in the Figure.

At the time of operation, the index in 16 of the $1 \delta$ patients was above the normal limit, while in two cases it was near the upper limit of the normal 95\% range (Figure).

One year after operation the index was reduced in 14 cases, was unchanged in two, and had

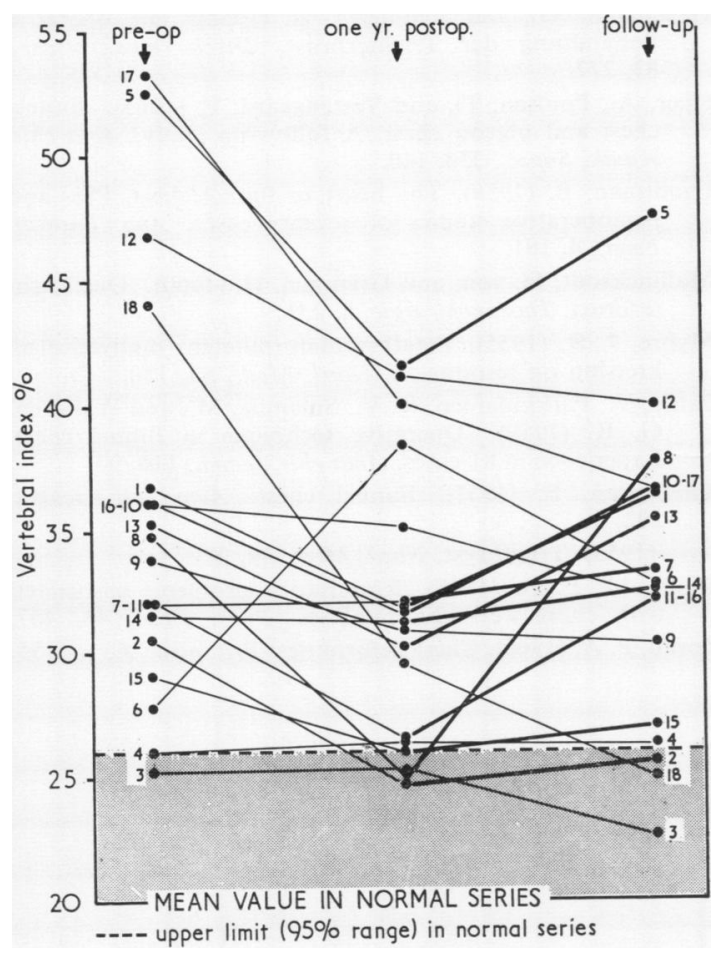

FIGURE Vertebral index in 18 patients with funnel chest.

increased in two $(\overline{\mathrm{x}}=-4 \cdot 75 \pm 1 \cdot 43)$. Clinical examination at that time (Kjær et al., 1965) showed satisfactory results in all cases except one.

On follow-up 7 to 10 years after the operation, the vertebral index had increased on average by $1.25 \pm 0.91 \%$ (Table). Ten of the 18 patients showed radiological signs of recurrence. With regard to the overall results of the operation, 8 of the 18 patients had improved.
T A B L E I

REVIEW OF MATERIAL WITH AN INDICATION OF THE CHANGES IN THE VERTEBRAL INDEX (BACKER $e_{t}$ al., 1961)

\begin{tabular}{|c|c|c|c|c|c|c|c|}
\hline \multirow[b]{2}{*}{$\begin{array}{l}\text { Pat- } \\
\text { ient } \\
\text { No. }\end{array}$} & \multirow[b]{2}{*}{$\operatorname{Sex}$} & \multirow[b]{2}{*}{$\begin{array}{c}\text { Age at } \\
\text { Opera- } \\
\text { tion } \\
(y r)\end{array}$} & \multicolumn{3}{|c|}{ Vertebral Index \% } & \multirow[b]{2}{*}{$\begin{array}{c}\text { Clinical } \\
\text { Evalua- } \\
\text { tion } \\
\text { Cosme- } \\
\text { tically }\end{array}$} & \multirow[b]{2}{*}{$\begin{array}{c}\text { Subjective } \\
\text { Result }\end{array}$} \\
\hline & & & $\begin{array}{l}1 \text { Year } \\
\text { Postop. }\end{array}$ & Fol- & $\begin{array}{c}\text { Overall } \\
\text { Result } \\
\text { of Oper- } \\
\text { ation }\end{array}$ & & \\
\hline $\begin{array}{r}1 \\
2 \\
3 \\
4 \\
5 \\
6 \\
7 \\
7 \\
8 \\
9 \\
10 \\
11 \\
12 \\
13 \\
14 \\
15 \\
16 \\
17 \\
18\end{array}$ & $\begin{array}{l}\mathbf{F} \\
\mathbf{F} \\
\mathbf{M} \\
\mathbf{M} \\
\mathbf{F} \\
\mathbf{M} \\
\mathbf{F} \\
\mathbf{M} \\
\mathbf{M} \\
\mathbf{M} \\
\mathbf{M} \\
\mathbf{M} \\
\mathbf{M} \\
\mathbf{M} \\
\mathbf{M} \\
\mathbf{M} \\
\mathbf{M} \\
\mathbf{M}\end{array}$ & $\begin{array}{r}15 \\
4 \\
15 \\
16 \\
17 \\
17 \\
18 \\
12 \\
6 \\
18 \\
14 \\
14 \\
17 \\
15 \\
14 \\
11 \\
18 \\
26\end{array}$ & $\begin{array}{r}-4.8 \\
-5.9 \\
0 \\
+0.4 \\
-11.1 \\
+10.5 \\
0 \\
-7.9 \\
=2.9 \\
=4.5 \\
=5.5 \\
=12.7 \\
=5.0 \\
=0.4 \\
=3.1 \\
=1.1 \\
=13.3 \\
-14.4\end{array}$ & $\begin{array}{l}+4.6 \\
+0.9 \\
+2.7 \\
+0.2 \\
+6.0 \\
+5.7 \\
+1.3 \\
+12.8 \\
+0.5 \\
+4.9 \\
+5.6 \\
+1.1 \\
+5.2 \\
+1.3 \\
+1.0 \\
+2.9 \\
=3.4 \\
-4.6\end{array}$ & $\begin{array}{l}-0.2 \\
=5.0 \\
=2.7 \\
+0.2 \\
+5.1 \\
+4.8 \\
+1.3 \\
+4.9 \\
+3.4 \\
+0.4 \\
+0.1 \\
-13.8 \\
+0.2 \\
\pm 0.9 \\
\pm 2.1 \\
=4.0 \\
=16.7 \\
-19.0\end{array}$ & $\begin{array}{l}\text { Poor } \\
\text { Good } \\
\text { Good } \\
\text { Poor } \\
\text { Poor } \\
\text { Good } \\
\text { Poor } \\
\text { Poor } \\
\text { Poor } \\
\text { Poor } \\
\text { Poor } \\
\text { Poor } \\
\text { Poor } \\
\text { Poor } \\
\text { Good } \\
\text { Poor } \\
\text { Poor } \\
\text { Good }\end{array}$ & $\begin{array}{l}\text { Satisfied } \\
\text { Satisfied } \\
\text { Satisfied } \\
\text { Satisfied } \\
\text { Satisfied } \\
\text { Satisfied } \\
\text { Satisfied } \\
\text { Unsatisfied } \\
\text { Satisfied } \\
\text { Satisfied } \\
\text { Unsatisfied } \\
\text { Satisfied } \\
\text { Unsatisfied } \\
\text { Satisfied } \\
\text { Satisfied } \\
\text { Satisfied } \\
\text { Satisfied } \\
\text { Satisfied }\end{array}$ \\
\hline$\underset{\text { Varia }}{\stackrel{\overline{\mathbf{x}}}{\mathbf{S}}}$ & & & $\begin{array}{r}-4.57 \\
1.43 \\
1.33\end{array}$ & $\begin{array}{r}1.25 \\
0.91 \\
3.09\end{array}$ & $\begin{array}{r}-3.3 \\
1.57 \\
2.03\end{array}$ & & \\
\hline
\end{tabular}

For comparison, both the clinical and subjective results of the follow-up are tabulated.

The clinical result was recorded as unsatisfactory in 13 of the patients evaluated on the basis of recurrence of the funnel chest and cosmetically disfiguring scars.

Only three patients were themselves dissatisfied with the result achieved.

\section{DISCUSSION AND CONCLUSION}

A satisfying evaluation of the results of operation for funnel chest is difficult by means of an ordinary clinical examination of the patient. This is apparent in patients 12 and 17, for example, where the results were classified as poor at the clinical examination, while the index shows a clear reduction in the degree of excavation. The explanation must presumably be sought in the very pronounced degree of funnel chest preoperatively, as seen from the preoperative index (Figure).

The three patients who were dissatisfied with the result of operation were all adult men. These were cases where the result was also evaluated as poor clinically, and where the overall result evaluated from the vertebral index showed a slight exacerbation from the preoperative status. However, as the Table shows, they were not among the most severe preoperative cases.

In the present series, the indications for operation have been cosmetically disfiguring funnel 
chest and the psychological upset associated with this. In a few patients there have also been uncharacteristic symptoms, such as frequent infections of the upper respiratory tract and palpitations. For this reason the time of operation was delayed until about the age of 14 years, when the cosmetic effect becomes important to the patient. In contrast to this, the majority of authors recommend that operation should be carried out at an earlier age, when the thoracic skeleton is softer and easier to correct (Gibbon, 1962; Therkelsen, 1951, 1953; Paltia et al., 1959). The results in the present material do not encourage delay in the time of operation, if indications for operation are found to be present.

From the point of view of the surgeon, the longterm cosmetic result is so poor that there should be great reservation in the decision to operate on patients who do not experience very pronounced discomfort or psychiatric symptoms.

The fact that most of the patients are satisfied witin the result is without doubt due in many cases to the time of follow-up coming at an age when the cosmetic discomforts of funnel chest are themselves reduced. Possibly also a disfiguring scar causes less mental stress than a congenital malformation.

\section{REFERENCES}

Ashmore, P. G. (1963). Management of some deformities of the thoracic cage in children. Canad. J. Surg., 6, 430.

Backer, O. G., Brünner, S., and Larsen, V. (1961). The surgical treatment of funnel chest. Acta chir. scand., 121, 253.
Brodkin, H. A. (1948). Congenital chondrosternal depres $-\sqrt{\overrightarrow{2}}$ sion (funnel chest) relieved by chondrosternoplastyAmer. J. Surg., 75, 716.

Dafoe, C. S., and Ross, C. A. (1961). The surgical treatmen of pectus excavatum utilizing an adhesive hemicast Dis. Chest, 40, 479.

Fabricius, J., Davidsen, H. G., and Hansen, A. Tybjaerg0 (1957). Cardiac function in funnel chest. Dan. med. Bull., 4, 251.

Flemming, F., and Neute, E. (1966). Zum Problem der Brustkorbstabilisierung nach Trichterbrustoperationen. $\vec{\omega}$ Chirurg, 37, 109.

Gibbon, J. H. Jr. (1962). Surgery of the Chest. W. B. Saunders, Philadelphia and London.

Hansen, J. L., and Jacoby, O. (1956). The respiratory? function before and following surgery in cases of. funnel chest. Acta chir. scand, 111, 226.

Hegemann, G., and Schoberth, H. (1958). Die operativeo Behandlung der Trichterbrust. Dtsch. med Wschr., 83, 277.

Kjær, A., Poulsen, T., and Vestengaard, E. (1965). Funne chest and pigeon chest. A follow-up study. Acta chir scand., Suppl., 356, 140.

Landtman, B. (1958). The heart in funnel chest. Pre- and postoperative studies of seventy cases. Ann. Paediatse Fenn., 4, 181.

Mallinckrodt, H. von, and Gremmel, H. (1960). Die Trich: terbrust. Thoraxchirurgie, 8, 135.

Myhre, J. R. (1955). Tragtbrystdeformitetens innflytelse pås kretsløp og respirasjon. Nord. Med., 53, 150.

Paltia, V., Parkkulainen, K. V., Sulamaa, M., and Wallgren G. R. (1959). Operative technique in funnel chest $\mathbb{D}$ Experience in 81 cases. Acta chir. scand., 116, 90.

Therkelsen, F. (1951). Funnel chest. Acta chir. scand., $102,36$. (1953). Tragtbryst. Nord. Med., 49, 281.

Wohl, M. E. B. (1968). Respiratory problems associate $\bar{P}$ with chest wall abnormalities. Phys. Ther., 48, 467

Zorab, P. A. (1966). Chest deformities. Brit. med., J., 1, 1155으 